\title{
Matric potential of clay loam soils on arid rangelands in southern New Mexico
}

\author{
CARLTON H. HERBEL AND ROBERT P. GIBBENS
}

\begin{abstract}
The matric potential of soil water is presented for 6 clay loam sites on floodplains of arid rangelands. Gypsum resistance blocks impregnated with plaster of paris were placed at 6 soil depths to 122 $\mathrm{cm}$. At 4 locations, blocks were placed inside and outside a buried sheet metal cylinder so that estimates could be obtained of matric potential due to precipitation and due to precipitation plus run-in. The average annual precipitation during the approximate 20-year study period was $242 \mathrm{~mm}$, slightly above the long-time average. Haplargids dominated by tobosa [Hillaria mutica (Buckl.)Benth.] had a greater probability of the matric potential $\geq-1.5 \mathrm{MPa}$ (wet soil) than the Calciorthids dominated by burrograss (Scleropogon brevifolius Phil.). The probability of matric potential $\geq-1.5 \mathrm{MPa}$ (wet soil) was as great or greater in winter as during the summer growing season. The factors affecting matric potential were amount and nature of precipitation, amount of run-in water, soil and vegetation type, position on the landscape, and microrelief.
\end{abstract}

Key Words: soil matric potential, precipitation, probabilities, soil texture

Forage production on arid rangelands is highly dependent on available soil water. Soil water deficits can cause large reductions in forage production. However, there is little information in scientific literature of field measurements of soil water on arid rangelands.

Herbel and Gibbens (1987) measured the matric potential of 11 coarse-textured sites in southern New Mexico for nearly 20 years. During the cool part of the year, December-April, the probability of soil matric potential $\geq-1.5 \mathrm{MPa}$ (wet) was $69 \%$ at the $10-\mathrm{cm}$ depth, $83 \%$ of the $69 \%$ was $\geq-0.1 \mathrm{MPa}$ (readily available). The probability of wet soils during the summer rainy season, July-September, was $53 \%$ at the $10-\mathrm{cm}$ depth, $73 \%$ of which was readily available. When the matric potential was $\leq-1.5 \mathrm{MPa}$ (dry), it took at least $13 \mathrm{~mm}$ precipitation in a single day to change to wet soils at the $10-\mathrm{cm}$ depth.

Tromble (1982) studied the volume of soil water on a fine-loamy, mixed, thermic, Typic Haplargid of the Dona Ana series with a $1 \%$ slope about $10 \mathrm{~km}$ from our study sites. Soil water content during the summer thunderstorm period averaged $13.5 \%$ for 2 years at depths of $30-180 \mathrm{~cm}$, but it was about $35 \%$ where water was ponded behind dikes $15 \mathrm{~cm}$ high. This indicates slow infiltration on this bare area with a slight slope. Overland flow was initiated with as little as $\mathbf{5 m m}$ of rainfall.

As much as $93 \%$ of the annual precipitation is lost by evaporation on sites dominated by creosotebush [Larrea tridentata (Sesse \& Mocino ex DC.) Coville] in the Sonoran Desert (Sammis and Gay 1979). On a site dominated by creosotebush in the Chihuahuan Desert, Schlesinger et al. (1987) estimated that $72 \%$ of precipitation was removed by transpiration. This suggests a tremendous variation in soil water losses due to evaporation and due to transpir-

\footnotetext{
Authors are range scientists, Jornada Experimental Range, Agricultural Research Service, U.S. Department of Agriculture, P.O. Box 30003-Dept. 3JER-NMSU, Las Cruces, New Mexico 88003-0003.

Cooperative investigations between the Agricultural Research Service, U.S. Department of Agriculture and the Agricultural Experiment Station, New Mexico State University. Journal article no. 1401, New Mexico Agricultural Experiment Station.

Manuscript accepted 13 December 1988.
}

ation. The latter authors also suggested that plant uptake of water from the lower soil profile greatly affects calcium carbonate (caliche) deposition in desert soils.

On loamy sands and sandy loams of the Jornada Experimental Range, factors affecting soil matric potential were precipitation amount, surface soil characteristics, topography, subsurface conditions, and season of the year (Herbel and Gibbens 1987). Information on soil water is needed to understand forage dynamics on flood plains of arid rangelands. This paper presents information on the soil matric potential of clay loams at several sites receiving run-in water from adjacent slopes. These data are unique because soil water potential was determined for nearly 20 years, and we attempted to determine soil water due to precipitation and due to precipitation plus run-in. It is the first attempt to quantify these measurements on clay loam soils on arid rangelands.

\section{Materials and Methods}

\section{Description of the Study Area}

This study was conducted on the Jornada Experimental Range about $40 \mathrm{~km}$ north of Las Cruces, New Mexico. Most of the Jornada is in a closed intermountain basin with a level to gently undulating topography. The average annual precipitation is 228 $\mathrm{mm}$ with $129 \mathrm{~mm}$ occurring during the July through September growing season. Most summer rainfall occurs as intensive thunderstorms. Conversely, winter precipitation from frontal storms is gentle. Description of other climatic features can be found in Herbel and Gibbens (1987).

Five locations, 6 sites, designated $\mathrm{V}, \mathrm{W}, \mathrm{X}, \mathrm{Y}_{2}, \mathrm{Y}_{3}$, and $\mathrm{Z}$, were sampled during the study. Table 1 shows the soil and the dominant plants at the 6 sampling sites and Table 2 shows the textural class and soil horizon for the depths where matric potentials were determined (Bulloch and Neher 1980, Herbel and Gile 1973). Both Sites $V$ and $Y_{2}$ occur on the toeslopes at the edge of the basin floor. The slope is about $0.5 \%$ and the vegetation is a dense stand of tobosa [Hilaria mutica (Buckl.) Benth.]. Toeslopes, such as $\mathrm{V}$ and $\mathrm{Y}_{2}$, may contribute some runoff water to the basin floor from a high-intensity storm, they also receive considerable run-in from the adjacent steeper slopes. Average annual tobosa production at $Y_{2}$ for 4 years was $3,005 \mathrm{~kg} / \mathrm{ha}$ (Herbel 1963). Site $Y_{3}$ is an inclusion of Reagan soil $4 \mathrm{~m}$ in diameter, dominated by burrograss (Scleropogon brevifolius Phil.), located $5 \mathrm{~m}$ from Site $\mathrm{Y}_{2}$. Locations $\mathrm{W}$ and $X$ occur on the relatively level basin floor. Run-in water from Table 1. Solls and dominant vegetation of 6 sites on the Jornada Experi-
mental Range.

\begin{tabular}{llll}
\hline \hline Site & Soil classification & Soil series & $\begin{array}{l}\text { Dominant } \\
\text { vegetation }\end{array}$ \\
\hline $\mathrm{V}, \mathrm{W}, \mathrm{Y}_{2}$ & $\begin{array}{c}\text { Ustollic Haplargid, fine, } \\
\text { mixed, thermic } \\
\text { Ustollic Calciorthid, fine-silty, Reagan } \\
\text { mixed, thermic }\end{array}$ & Stellar & iobosa \\
$\mathrm{X} \mathrm{Y}_{3}$ & $\begin{array}{c}\text { Typic Calciorthid, fine-loamy, Algerita } \\
\text { mixed, thermic }\end{array}$ & $\begin{array}{l}\text { Tobosa- } \\
\text { burrograss }\end{array}$ \\
$\mathrm{Z}$ & & \\
\hline
\end{tabular}


Table 2. Soil texture (horizon) for the study depths at six sites at the Jornada Experimental Range.

\begin{tabular}{|c|c|c|c|c|c|c|}
\hline \multirow[b]{2}{*}{ Site } & \multicolumn{6}{|c|}{ Depth (cm) } \\
\hline & 10 & 25 & 41 & 61 & 91 & 122 \\
\hline $\begin{array}{l}\mathrm{V} \\
\mathrm{W} \\
\mathrm{X} \\
\mathrm{Y}_{2} \\
\mathrm{Y}_{3} \\
\mathrm{Z}\end{array}$ & $\begin{array}{l}\operatorname{cl}(A) \\
\operatorname{c(Btl)} \\
\operatorname{sicl}(A B) \\
\operatorname{cl}(B A t) \\
\operatorname{sicl}(A) \\
\text { fsl(A) }\end{array}$ & $\begin{array}{l}\operatorname{cl}(B t 1) \\
\operatorname{cl}(B t 2) \\
\operatorname{cl}(B A) \\
\operatorname{c(Bt1)} \\
\text { sicl(Bwl) } \\
\operatorname{cl}(B A 1)\end{array}$ & $\begin{array}{l}\text { cl(Bt1) } \\
\text { cl(Bt2) } \\
\text { sicl(Bk1) } \\
\text { c(Bt1) } \\
\text { cl(Bw2) } \\
\operatorname{scl}(B A 2)\end{array}$ & $\begin{array}{l}\text { cl(Bt2) } \\
\text { c(Btk) } \\
\text { cl(Bk2) } \\
\text { c(Bt2) } \\
\text { sicl(Bk) } \\
\text { sicl(Bk1) }\end{array}$ & $\begin{array}{l}\text { c(Bk) } \\
\text { cl(Bk1) } \\
\text { cl(Bk3) } \\
\operatorname{sicl}(B k) \\
\operatorname{sicl}(B k) \\
\operatorname{sicl}(B k 3)\end{array}$ & $\begin{array}{l}\text { c(2Bt) } \\
\text { cl(Bk2) } \\
\text { cl(Btkb) } \\
\text { cl(Bky) } \\
\text { cl(2Bt) } \\
\text { sl(2Bky2) }\end{array}$ \\
\hline
\end{tabular}

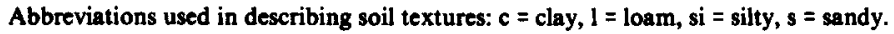

the adjacent slopes does not stand on the area, but drains slowly to a playa about $2 \mathrm{~km}$ distant. The vegetation at Location $W$ is tobosa and the average $1957-77$ production was $1,662 \mathrm{~kg} / \mathrm{ha}$ (Herbel and Gibbens 1981). The tobosa at $W$ is sparser than at $V$ and $Y_{2}$. Location $X$ is about $75 \mathrm{~m}$ from $W$ and dominated by burrograss that averaged $950 \mathrm{~kg} / \mathrm{ha} 1957-77$. Location $Z$ is in a small playa at the end of a drainageway that begins on the slopes of mountains about $16 \mathrm{~km}$ distant. The playa is flooded about twice every 3 years. The vegetation is a mixture of tobosa and burrograss that averaged $1,710 \mathrm{~kg} / \mathrm{ha} 1957-77$ (Herbel and Gibbens 1981 ).

The soils at $\mathrm{V}, \mathrm{W}$, and $\mathrm{Y}$ were formed in fan-piedmont sediments derived from monzonite, rhyolite, and andesite; at $\mathrm{X}$, the soil was formed in basin floor sediments derived primarily from sedimentary rocks with lesser amounts from igneous rocks; and at $Z$, the soil was formed in alluvium from sedimentary and igneous rocks resting on gypsum of lacustrine origin (Herbel and Gile 1973). The surface was Pleistocene age (Gile and Hawley 1968, Hawley and Gile 1966).

\section{Measurement Techniques}

Gypsum resistance blocks impregnated with plaster of paris were placed at depths of $10,25,41,61,91$, and $122 \mathrm{~cm}$. At 4 locations (W, $X, Y$, and $Z$ ) blocks were placed inside and outside a sheet-metal cylinder. The cylinder was $3 \mathrm{~m}$ in diameter, was buried $15 \mathrm{~cm}$ in the soil, and extended $15 \mathrm{~cm}$ above the soil surface. The blocks inside the cylinder provided estimates of the matric potential due to precipitation while those outside the cylinder provided estimates of the matric potential due to precipitation plus run in. The subscript numbers 0 and 1 identify sites inside the cylinder and the subscript numbers 2 and 3 identify sites outside the cylinder. At Site $Y_{2}, 2$ sets of blocks were inside the cylinder, identified as $Y_{0}$ and $Y_{1}$. At this site, the cylinder did not completely block run-in water because water that accumulated in a depression outside the cylinder was able to infiltrate and move laterally through natural soil pipes or tubes to the Btl horizon. The matric potential at the location was also measured in a relatively small inclusion of burrograss outside the cylinder in an otherwise thick stand of tobosa (Site $\mathrm{Y}_{3}$ ).

All sampling sites were located within livestock exclosures. Matric potential measurements were recorded with an ohmmeter 1 to 3 times per week when the soil was wet during the summer. Measurements were recorded monthly during the remainder of the year when there were fewer changes in soil water status. Blocks were calibrated in medium-textured soil by determining their resistance in a pressure plate extractor (Taylor et al. 1961). Only blocks with similar response curves were used. Occasionally, blocks were replaced because of rodent damage to wires. No deterioration of the gypsum medium occurred in these aridisols. No change in calibration of the blocks was observed. All resistance readings were corrected to $15.6^{\circ} \mathrm{C}$ using soil temperatures recorded with thermistors at several soil depths at 4 locations when matric potential was measured. Precipitation was recorded at each study site in a stand- ard U.S. Weather Bureau rain gauge modified to reduce evaporation loss (Gomm 1961).

The soils in this study were nonsaline as determined by a method developed by the U.S. Salinity Laboratory (1954). Therefore, the measurement of the soil water was assumed to be a measure of the matric potential. Each resistance reading was translated to $\mathrm{MPa}$. For days when the resistance was not measured, matric potential was determined by (1) previous determinations of matric potential at that depth, (2) current precipitation, (3) matric potential at other depths at that location, and (4) previous precipitation events at that location. All the daily determinations were grouped into matric potentials of 0 to $-0.1 \mathrm{MPa}$ (readily available), -0.1 to $-1.5 \mathrm{MPa}$, and <-1.5 $\mathrm{MPa}$ (dry).

Resource availability dictated the establishment of sampling sites. Blocks were installed at the 10-,25-, and 41-cm depths at Sites $V, W_{2}, X_{2}$, and $Z_{2}$ in July 1957; and at Site $Y_{2}$ in July 1958. The remainder of the blocks were installed in August 1959. Resistance readings were terminated 31 Dec. 1976 . No readings were obtained 1 Aug. through 31 Dec. 1972 because of a meter failure.

Soil matric potential was determined for each day. Probabilities were calculated by determining the percentage of days in each month at each study site at each depth that had matric potentials (1) >-0.1 $\mathrm{MPa}$, (2) between -0.1 and $-1.5 \mathrm{MPa}$, and (3)<-1.5 $\mathrm{MPa}$, and then averaging these percentages for the entire study period. For the probability of wet soils, $\geq-1.5 \mathrm{MPa}$, we combined (1) and (2). Thus, for purposes of this paper, a matric potential of $\geq-1.5 \mathrm{MPa}$ is considered a wet soil with water available to plants. A metric potential of $\geq-0.1 \mathrm{MPa}$ shows the soil very wet with water readily available to plants while soil water with a matric potential $<-1.5 \mathrm{MPa}$ is considered dry soil. Some plants use soil water $<-1.5$ $\mathrm{MPa}$. This broad interpretation minimizes the effect of hysteresis of the blocks.

Table 3. Averase monthly precipitation (mm) at 3 locations, 1957-76, on the Jornada Experimental Range.

\begin{tabular}{lrrr}
\hline & \multicolumn{3}{c}{ Location } \\
\cline { 2 - 4 } Month & V & W & Z \\
\hline & & mm & \\
\cline { 2 - 4 } Jan. & 13 & 11 & 10 \\
Feb. & 7 & 6 & 7 \\
Mar. & 8 & 8 & 6 \\
Apr. & 3 & 3 & 3 \\
May & 5 & 4 & 3 \\
June & 16 & 14 & 16 \\
July & 60 & 50 & 46 \\
Aug. & 58 & 58 & 41 \\
Sep. & 44 & 40 & 47 \\
Oct. & 25 & 17 & 19 \\
Nov. & 12 & 11 & 10 \\
Dec. & 16 & 14 & 16 \\
Total & 267 & 236 & 224 \\
\hline
\end{tabular}


JUN JUL
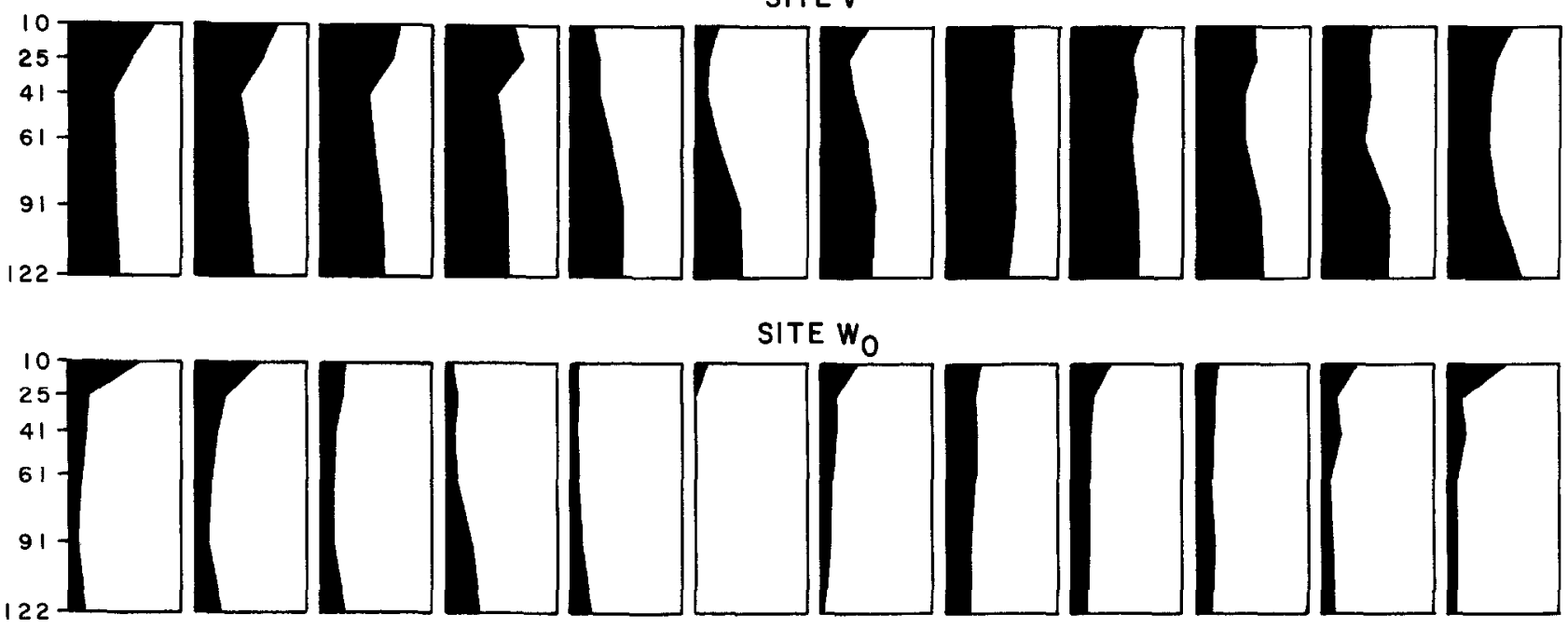

SITE $W_{0}$
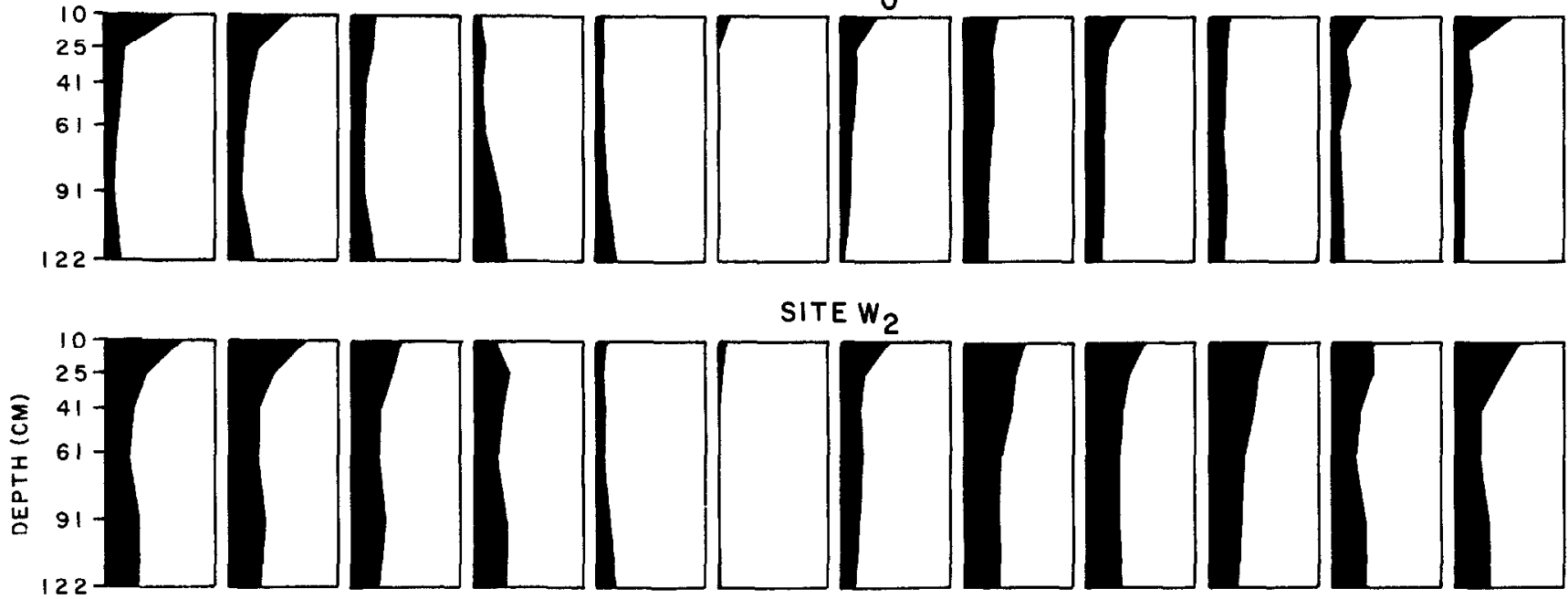

SITE $W_{2}$
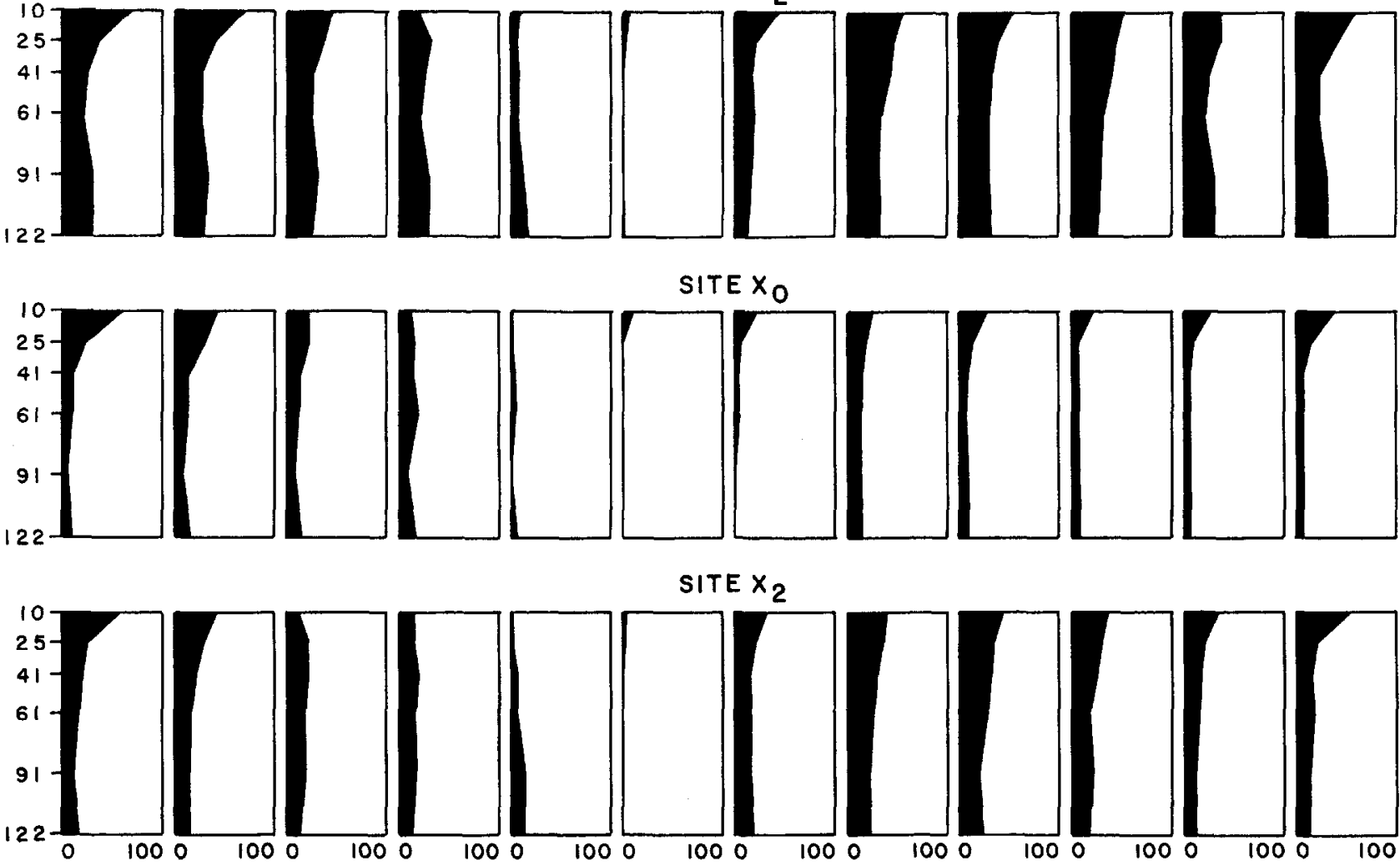

\section{SITE $X_{2}$}

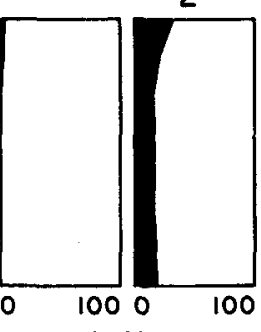

PERCENT
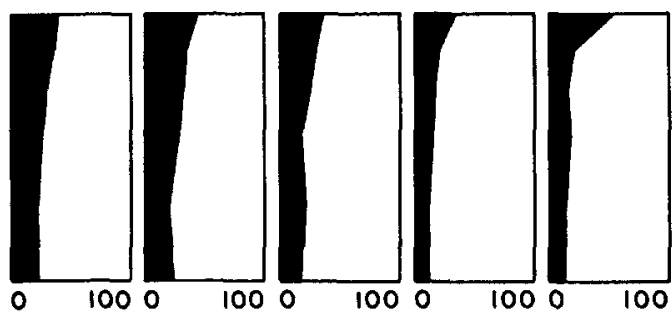

Fig. 1. Monthly probability (\%) of the matric potential $\geq-1.5 \mathrm{MPa}$ (wet soils) for 6 depths at Locations, $\mathrm{V}, \mathrm{W}$, and $X$.

\section{Results and Discussion}

The average annual precipitation for Locations $\mathrm{V}, \mathrm{W}$, and $\mathrm{Z}$ was 267,236 , and $224 \mathrm{~mm}$, respectively, and the average rainfall for July-Sep. was 162, 148, and $134 \mathrm{~mm}$ (Table 3). The precipitation for $V$ and $Y$, and for $W$ and $X$, is similar because they are close to each other. Inspection of daily precipitation and matric potential revealed, when the soil was dry, it took at least $20 \mathrm{~mm}$ precipitation in a single day to change a wet soil at the $10-\mathrm{cm}$ depth, particularly in the warm days of June-Aug. Correlations between precipitation, all daily events or daily events $\geq 20 \mathrm{~mm}$, and matric potentials at the various locations were low $(r \leq 0.32)$.

\section{Soil Matric Potentials}

\section{Location $V$}

Figure 1 shows the monthly probabilities of wet soil for all study depths of $V, W$, and $X$. The annual probabilities of wet soil for $V$ ranged from 39-53\%. Except for May, July, and August, the lowest probabilities of wet soil were at the $41-$ and $61-\mathrm{cm}$ soil depths. Evapotranspiration did not seem to have a large effect on the matric potential at the 91 - and 122-cm depths. As soil temperature declined, there apparently was an increase in the probabilities 

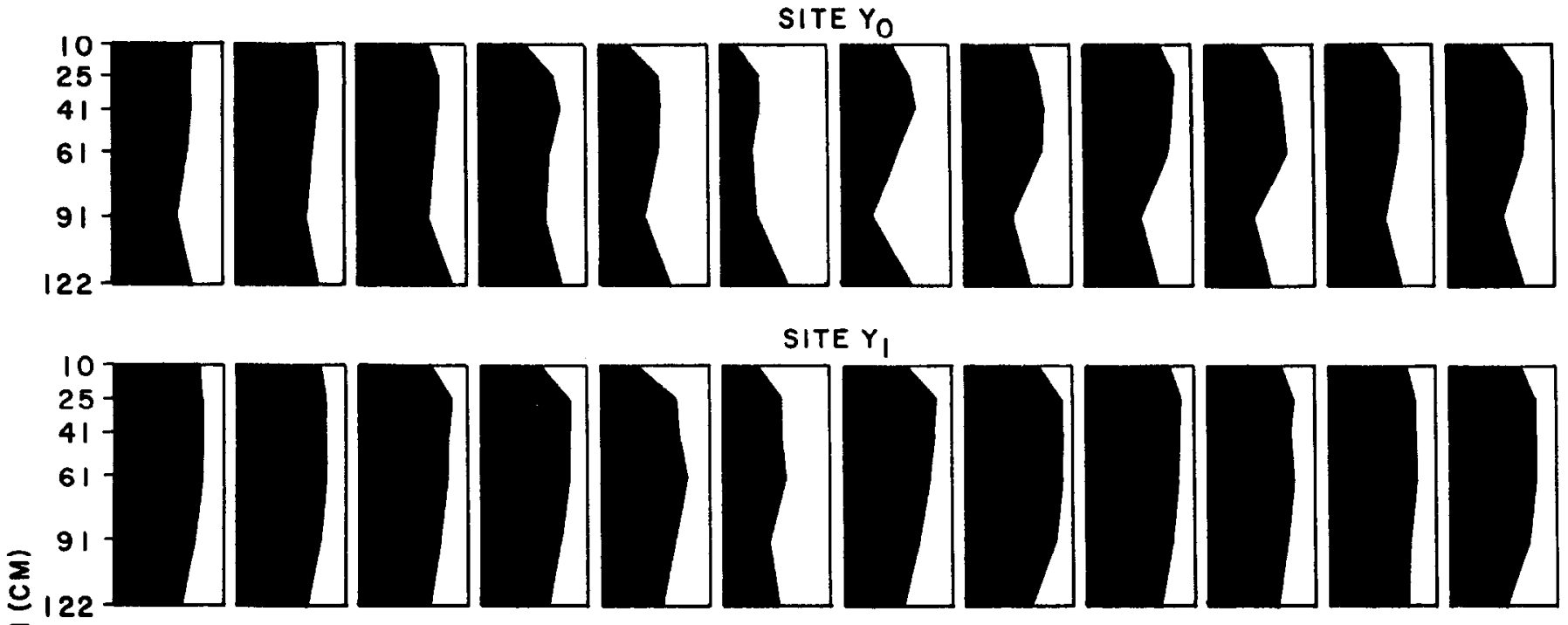

占
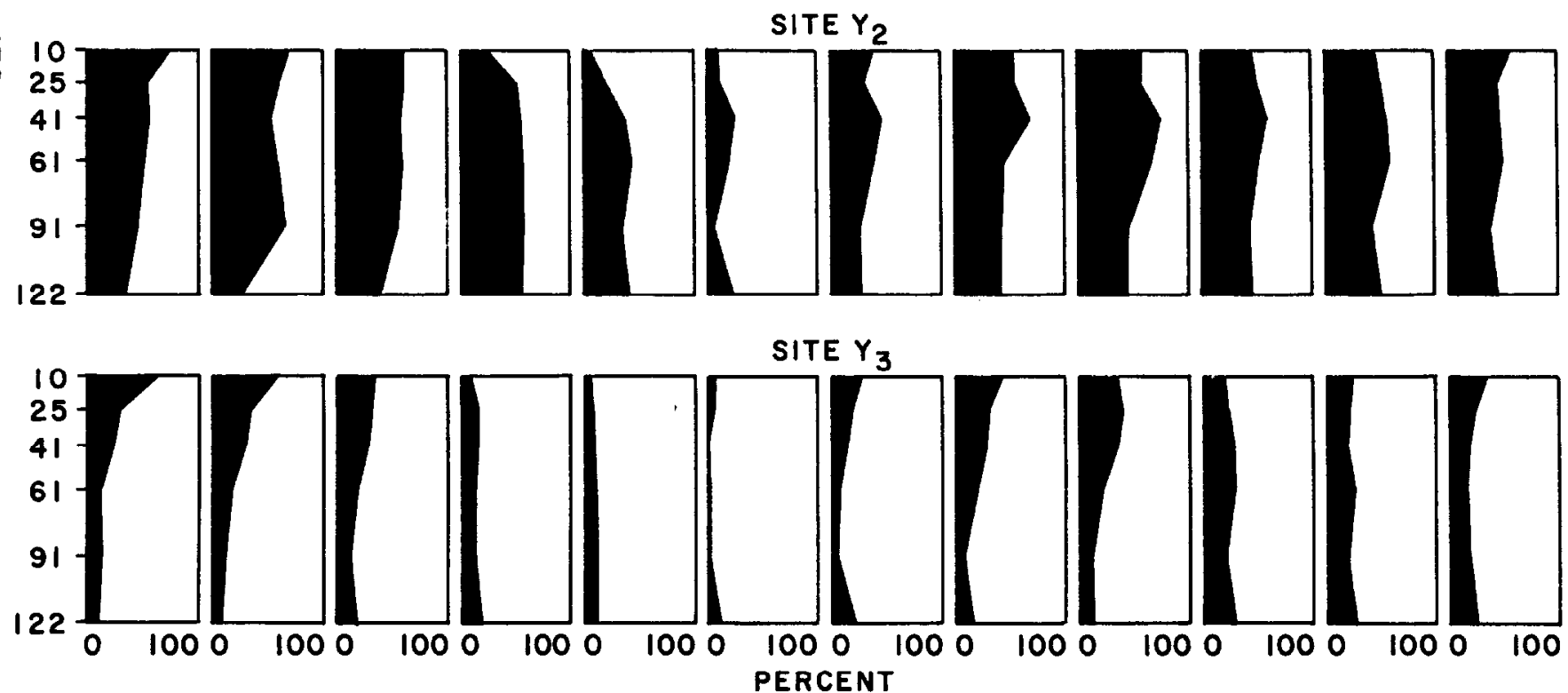

Fig. 2. Monthly probability (\%) of the matric potential $\geq-1.5 \mathrm{MPa}$ (wet soils) for 6 depths at Location Y.

of wet soil at the $122-\mathrm{cm}$ depth from the calcium carbonate (caliche) underlying this soil (Hennessy et al. 1983, Taylor 1962). In the $\mathrm{A}$ horizon at the $10-\mathrm{cm}$ depth, the probabilities of wet soil were lowest in May and June while the highest was Jan.-Mar. The lowest probabilities of wet soil at the other depths was in June. During summer, when average precipitation is the highest, the average probability of wet soil at the 10-cm depth was highest in September. The average lowest probabilities during summer were at the Bt $\mathrm{l}$ horizon at the 25- and 41-cm depths. During Nov.-Apr., average lowest probabilities of wet soil were at the $41-$ and $61-\mathrm{cm}$ depths.

\section{Location $W$}

The annual probability of wet soil for $W_{0}$ averaged $10-30 \%$ for the 6 soil depths where matric potentials were determined, whereas at $W_{2}$ the annual average was $21-43 \%$ (Fig. 1). In the Bt 1 horizon at the $10-\mathrm{cm}$ depth, the average annual probability of wet soil was $43 \%$ greater at $W_{2}$ than at $W_{0}$; at deeper depths, it was about $100 \%$ greater. Probabilities of wet soil at a depth of $10 \mathrm{~cm}$ at $W_{0}$ during Dec.-Feb. were $57 \%$, and 33\% during July-Sep. At $\mathrm{W}_{2}$, the probabilities of wet soil at the $10-\mathrm{cm}$ depth were $65 \%$ during Dec.-Feb., and $51 \%$ during July-Sep. At $W_{0}$, the probabilities of wet soil were at least $100 \%$ greater at the $122-\mathrm{cm}$ depth than at the $91-\mathrm{cm}$ depth for Jan.-Mar. and May. During Apr., the probabilities of wet soil at both the 91 - and $122-\mathrm{cm}$ depths were $>100 \%$ more than at the $61-\mathrm{cm}$ depth. These differences were not apparent at $W_{2}$. At both sites, the probabilities of wet soil were considerably higher during Dec.-Feb., July, and Sep. at the 10-cm depth then at the remaining soil depths.

\section{Location $X$}

The probability of wet soil was at least $100 \%$ greater at each depth for the average of July-Dec. at $\mathbf{X}_{2}$ than at $\mathbf{X}_{0}$, while it was similar for Jan.-June (Fig. 1). The highest probabilities for each month at $X_{0}$ and $X_{2}$ occurred in the $A B$ horizon at the $10-\mathrm{cm}$ depth, except for Mar.-May. At $X_{2}$, the probabilities of wet soil at the 10 -cm depth were $50 \%$ during Dec.-Feb., and $38 \%$ during July-Sep. The same probabilities at the $25-\mathrm{cm}$ depth were $25 \%$ and $30 \%$. At $\mathrm{X}_{0}$, the probabilities of wet soil were at least $100 \%$ greater during Jan.-May at the $122-\mathrm{cm}$ depth than at the $91-\mathrm{cm}$ depth. These pronounced differences did not occur at $X_{2}$. At both sites, the probabilities of wet soil were higher during June-Feb. at the 10-cm 


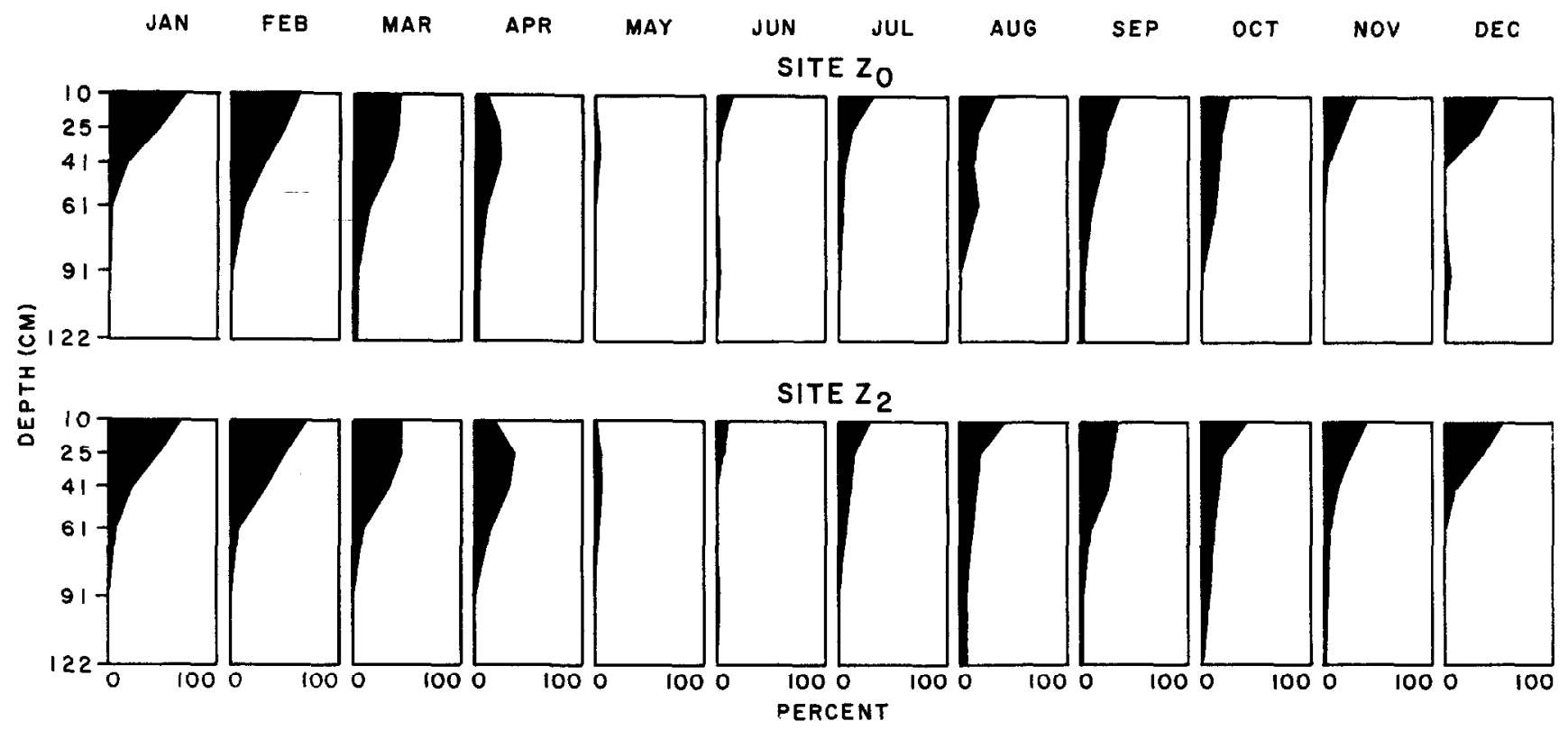

Fig. 3. Monthly probability (\%) of the matric potential $\geq-1.5 \mathrm{MPa}$ (wet soils) for 6 depths at Location $\mathrm{Z}$.

depth than the other soil depths.

\section{Location $Y$.}

The annual probabilities of wet soil for the 6 soil depths averaged $51-70 \%$ at $Y_{0}, 61-81 \%$ at $Y_{1}, 39-53 \%$ at $Y_{2}$, and $12-31 \%$ at $Y_{3}$ (Fig. 2). The probabilities for July-Sep. were $42-76 \%$ at $Y_{0}, 61-88 \%$ at $Y_{1}, 37-63 \%$ at $Y_{2}$, and $9-36 \%$ at $Y_{3}$, while for Nov.-Apr. they were $59-75 \%$ at $Y_{0}, 63-82 \%$ at $Y_{1}, 42-56 \%$ at $Y_{2}$, and $14-37 \%$ at $Y_{3}$. Although surface runoff was prevented inside the sheet metal cylinder at $Y_{0}$ and $Y_{1}$, the probability of wet soil was higher at $Y_{0}$ and $Y_{1}$ than at $Y_{2}$. The probabilities at the 25- to 91-cm soil depths were 4-6\% higher during July-Sep. than Nov.-Apr. at $Y_{1}$ whereas at $Y_{0}$ the probabilities for the 2 periods were similar at all depths sampled. At $Y_{0}$, every month had a higher probability of wet soil at the 122-cm depth than the $91-\mathrm{cm}$ depth, but at $Y_{1}$, most months had a higher probability at the $91-\mathrm{cm}$ depth than at the $122-\mathrm{cm}$ depth. At $Y_{2}$, with the exception of the 41-cm depth, the probability of wet soil was higher during Nov.-Apr. than July-Sep.

\section{Location Z}

At the $A$ horizon at the $10-\mathrm{cm}$ depth, the average probability for wet soil at $Z_{2}$ was $37 \%$ greater for Nov.-Apr. than for July-Sep. (Fig. 3). Also at the 10-cm depth, the probabilities for July-Sep. were $9 \%$ higher at $Z_{2}$ than at $Z_{0}$; for Nov.-Apr. it was $12 \%$. The highest probabilities for each month at $Z_{0}$ and $Z_{2}$ occurred at the 10-cm depth, except for Mar.-May.

\section{Soll Matric Potential >-0.1 MPa}

Table 4 shows the percentage of wet soil that is readily available for $V, Y_{0}, Y_{1}$, and $Y_{2} ;$ for $Y_{3}, W_{2}, X_{2}$, and $Z_{2}$; and for $W_{0}, X_{0}$, and $Z_{0}$. A greater percentage of soil water was readily available at the tobosa-dominated sites near slopes providing run-in water $\left(V, Y_{0}\right.$, $Y_{1}, Y_{2}$ ) than at the other sites, with the exception of the 122-cm depth during July-Mar. Generally, the burrograss-dominated site at $Y_{3}$, and the other sites receiving less run-in $\left(W_{2}, X_{2}, Z_{2}\right)$ were intermediate in the percentage of soil water that was readily available. During Apr.-June, when the soil was in a drying trend, more of the matric potential $\geq-1.5 \mathrm{MPa}$ was between -1.5 and $-0.1 \mathrm{MPa}$, except for soil depths between 25 and $91 \mathrm{~cm}$ at $V, Y_{0}, Y_{1}$, and $Y_{2}$.

\section{Variability Among Years}

Figure 4 shows the percentage of days during 3-month periods with matric potential >-1.5 MPa (wet) for the 6 soil depths and precipitation for 5 years $(1963,1965,1969,1970$, and 1975) at Location V. These data are typical of those obtained at other locations, and illustrate the variability among years.

Total precipitation for 1963 was $252 \mathrm{~mm}$ (average during study period $=267 \mathrm{~mm}$ ). The precipitation during this year can be characterized as a dry winter and spring, wet summer, and dry fall. The

Table 4. The average probabilities of soll matric potential $\geq-0.1 \mathrm{MPa}$ (readily available soil water) as a percentage of matric potential $\geq-1.5 \mathrm{MPa}$ (wet soils) for the sample sites, Jornada Experimental Range. Subscripts 0 and 1 denote sites within metal cyllnders, subscripts 2 and 3 outside cylinders.

\begin{tabular}{|c|c|c|c|c|c|c|}
\hline & \multicolumn{3}{|c|}{ July through March } & \multicolumn{3}{|c|}{ April through June } \\
\hline & $\mathbf{V}, \mathbf{Y}_{0}, \mathbf{Y}_{1}, \mathbf{Y}_{2}$, & $\mathbf{Y}_{3}, \mathbf{W}_{2}, \mathbf{X}_{2}, \mathbf{Z}_{2}$ & $\mathbf{W}_{0}, \mathbf{X}_{0}, \mathbf{Z}_{0}$ & $V, Y_{0}, Y_{1}, Y_{2}$ & $Y_{3}, W_{2}, X_{2}, Z_{2}$ & $\mathbf{W}_{\mathbf{0}}, \mathbf{X}_{0}, \mathbf{Z}_{0}$ \\
\hline \multicolumn{7}{|c|}{$\begin{array}{l}\text { Depth } \\
\text { (cm) }\end{array}$} \\
\hline 10 & 66 & 57 & 48 & 35 & 32 & 21 \\
\hline 25 & 79 & 67 & 57 & 67 & 22 & 20 \\
\hline 41 & 78 & 65 & 50 & 71 & 21 & 13 \\
\hline 61 & 70 & 58 & 47 & 61 & 25 & 23 \\
\hline 91 & 57 & 47 & so & 66 & 21 & 9 \\
\hline 122 & 29 & 41 & 40 & 27 & 20 & 12 \\
\hline
\end{tabular}


10 CM DEPTH

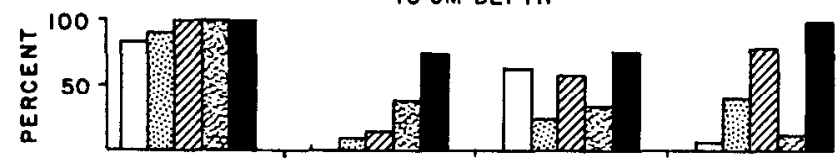

25 CM DEPTH

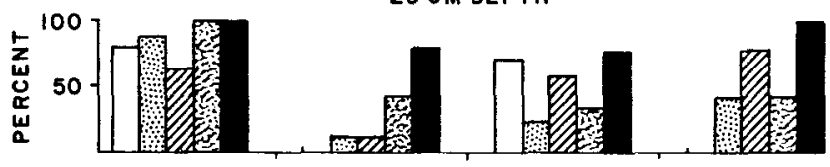

4I CM DEPTH

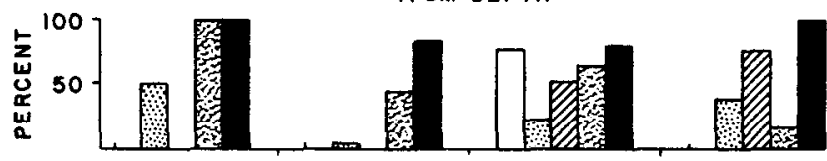

6I CM DEPTH

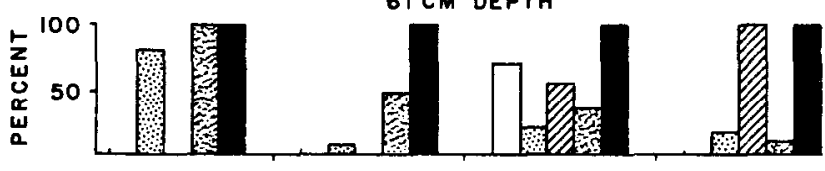

$91 \mathrm{CM}$ DEPTH

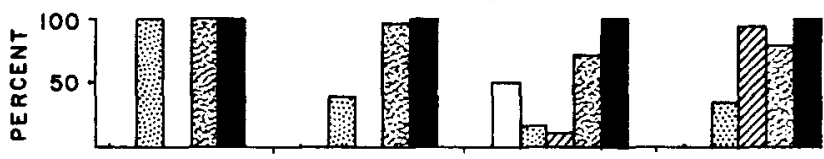

122 CM DEPTH

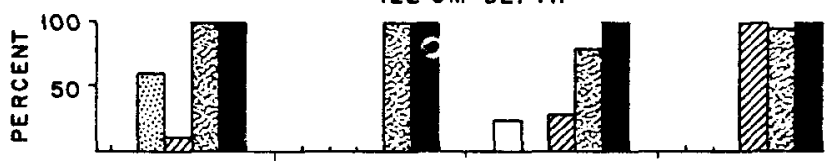

PRECIPITATION



Fig. 4. Percentage of days with matric potential $\geq-1.5 \mathrm{MPa}$ (wet soils) and precipitation $(\mathrm{mm})$ for 5 years at Location $V$.

precipitation during Jan.-Mar. was only $9 \mathrm{~mm}$, but the probability of wet soil was $83 \%$ at the $10-\mathrm{cm}$ depth and $80 \%$ at the $25-\mathrm{cm}$ depth from precipitation in fall 1962. Rainfall during July-Sep. was 181 $\mathrm{mm}$ (average $=162 \mathrm{~mm}$ ). The probability of wet soil was above average during the summer growing season, but was very low in spring and fall.

The year 1965 had $187 \mathrm{~mm}$ precipitation at Location V. The winter was wet with $143 \%$ of average precipitation and the probability of wet soil averaged $79 \%$ at the 6 soil depths. Precipitation during summer was only $52 \%$ of average, and the probability of wet soil was $18-26 \%$ at the 10 - through $91-\mathrm{cm}$ depths. The soil at the $122-\mathrm{cm}$ depth was always dry. Although precipitation during fall was $13 \%$ above average, probability of wet soil was only $30 \%$ at the 6 soil depths.

Precipitation during 1969 was $88 \%$ of average. The probability of wet soil during winter was relatively high at the $10-$ and $25-\mathrm{cm}$ depths, but decreased rapidly in April. Rainfall in summer was
$75 \%$ of average, but the probability of wet soil was more than $50 \%$ at the 10-through $61-\mathrm{cm}$ soil depths. Precipitation for Oct.-Dec. was $128 \%$ of average and the probability of wet soil averaged $88 \%$.

The year 1970 can be characterized as a dry year, but the probability of wet soil at all soil depths was relatively high during Jan.-June, and was high at the 91- and 122-cm depths the entire year. Rainfall was $51 \%$ and $19 \%$ of average during July-Sep. and Oct.-Dec., respectively, and the probability of wet soil for the 6 depths averaged 54 and $44 \%$, respectively.

The probability of wet soil was considerably above average at all 6 depths for the entire year in 1975. Precipitation was above average in winter and summer, but 25 and $81 \%$ of average in spring and fall, respectively. Primarily because of the high summer rainfall, total precipitation for 1975 was $341 \mathrm{~mm}$ or $28 \%$ above average.

\section{Conclusions}

Much of the rainfall in the warm season in this arid region falls during torrential thunderstorms, and runoff occurs on slopes. This provides additional soil water to sites below the slopes as evidenced by $Y_{0}, Y_{1}, W_{2} X_{2}$, and $Z_{2}$. A depression and soil tubes provided additional run-in water to $Y_{0}$ and $Y_{1}$ compared to $Y_{2}$. Stellar soils dominated by tobosa (Locations $W$ and $Y_{2}$ ) had a greater probability of the matric potential $\geq-1.5 \mathrm{MPa}$ (wet soil) than the Reagan soils dominated by burrograss at the same relative position on the landscape ( $\mathrm{W}$ vs $\mathrm{X}, \mathrm{Y}_{2}$ vs $\mathrm{Y}_{3}$ ). The matric potential was reduced when a drainageway was a considerable distance from piedmont slopes that had runoff water $\left(Z_{2}\right.$ vs. $V$ or $\left.Y_{2}\right)$. Infiltration rates at $X$ were reduced by the presence of silty, platy structure, $3 \mathrm{~mm}$ thick, at the soil surface. This decreased soil water also contributed to a higher calcium content in the Reagan than the Stellar soils.

Most of the precipitation during the cool season is gentle and light. Most of the winter soil water is from rainfall and run-in during late summer and fall. Apparently, there was some upward movement of soil water in late winter from the caliche layer below our deepest observation to the $122-\mathrm{cm}$ depth. This was particularly evident in observations at $W_{0}, X_{0}$, and $Y_{0}$.

Mcst of the soil water that remains from winter is evaporated during the normally dry spring periods. Therefore, most burrograss and tobosa production must occur during summer when conditions are favorable for plant growth. This study showed that daily precipitation $<20 \mathrm{~mm}$ did not contribute to soil water of dry soils at the 10-cm depth.

The probability of wet soil was as great or greater in winter as during the summer growing seasons. This indicates a potential for cool-season plants on these floodplains dominated by tobosa and burrograss. Unpublished information by the authors indicates disturbance (e.g., plowing) of these sites resulted in a dense stand of russianthistle (Salsola iberica Sennen \& Pau.). Russianthistle, an annual forb, can be established on moisture available in late winter, and the young plants provide nutritious livestock forage in early spring when nutrients are in short supply.

The severe drought of 1951-56 did not reduce the burrograss and tobosa cover on these sites as it did black grama [Bouteloua eriopoda (Torr.) Torr.] on coarse-textured soils (Herbel et al. 1972). Apparently, soil water is sufficient during droughty years to reduce mortality of burrograss and tobosa, but production is dramatically reduced by dry weather (Herbel and Gibbens 1981).

Nature and amount of precipitation, amount of run-in water, soil and vegetation type, position on the landscape, and microrelief are variable and have a marked effect on the matric potential of soil water. Precipitation values alone can be misleading when evaluating matric potential. The extreme variability of the matric potential results in a highly variable forage crop. The variability encountered can only be accommodated by highly flexible management strategies. 


\section{Literature Cited}

Bulloch, H.E., Jr., and R.E. Neher. 1980. Soil survey of Dona Ana County area of New Mexico. Soil Conserv. Serv., USDA, Washington, D.C.

Gile, L.H., and J.W. Hawley. 1968. Age and comparative development of desert soils at the Gardner Spring radiocarbon site, New Mexico. Soil Sci. Soc. Amer. Proc. 32:709-716.

Gomm, F.B. 1961. A modification of the standard Weather Bureau rain gauge for summer and winter use. Bull., Amer. Meteorol. Soc. 42:311-313.

Hawley, J.W., and L.H. Gile. 1966. Landscape evolution and soil genesis in the Rio Grande Region, southern New Mexico. Guidebook, 11 th Annu. Field Conf., Rocky Mountain Sect., Friends of the Pleistocene, University Park, N. Mex.

Hennessy, J.T., R.P. Gibbens, J.M. Tromble, and M. Cardenas. 1983. Water properties of caliche. J. Range Manage. 36:723-726.

Herbel, C.H. 1963. Fertilizing tobosa on flood plains in the semidesert grassland. J. Range Manage. 16:133-138.

Herbel, C.H., F.N. Ares, and R.A. Wright. 1972. Drought effects on a semidesert range. Ecology 53:1084-1093.

Herbel, C.H., and R.P. Gibbens. 1981. Drought and grazing management decisions, p. 187-192. In: Proc., 1981 Int. Rancher's Roundup, Del Rio, Texas, (eds. L.D. White and A.H. Hoermann), Tex. Agr. Ext. Serv., College Station.
Herbel, C.H., and R.P. Gibbens. 1987. Soil water regimes of loamy sands and sandy loams on arid rangelands in southern New Mexico. J. Soil and Water Conserv. 42:442-447.

Herbel, C.H., and L.H. Gile. 1973. Field moisture regimes and morphology of some arid-land soils in New Mexico, p. 119-152. In: Field Soil Water Regime, (eds. R.R. Bruce, K.W. Flach, and H.M. Taylor), Soil Sci. Soc. Amer. Spec. Pub. 5, Madison, Wisc.

Sammis, T.W., and L.W. Gay. 1979. Evapotranspiration from an arid zone plant community. J. Arid Environ. 2:313-321.

Schlesinger, W.H., P.J. Fonteyn, and G.M. Marion. 1987. Soil moisture content and plant transpiration in the Chihuahuan Desert of New Mexico. J. Arid Environ. 12:119-126.

Taylor, S.A. 1962. The influence of temperature upon the transfer of water in soil systems. Overdruk Uit de Mededelingen van de Landbouwhogeschool en de Opzoekingsstations van de steat te Gent 27:535-551.

Taylor, S.A., D.D. Evans, and W.D. Kemper. 1961. Evaluating soil water. Utah Agr. Exp. Sta. Bull. 426.

Tromble, J.M. 1982. Waterponding for increasing soil water on arid rangelands. J. Range Manage. 35:601-603.

U.S. Salinity Laboratory Staff. 1954. Methods for soil characterization, $p$. 83-126. In: L.A. Richards (ed.) Diagnosis and improvement of saline and alkali soils. USDA Handb. 60 , Washington, D.C.

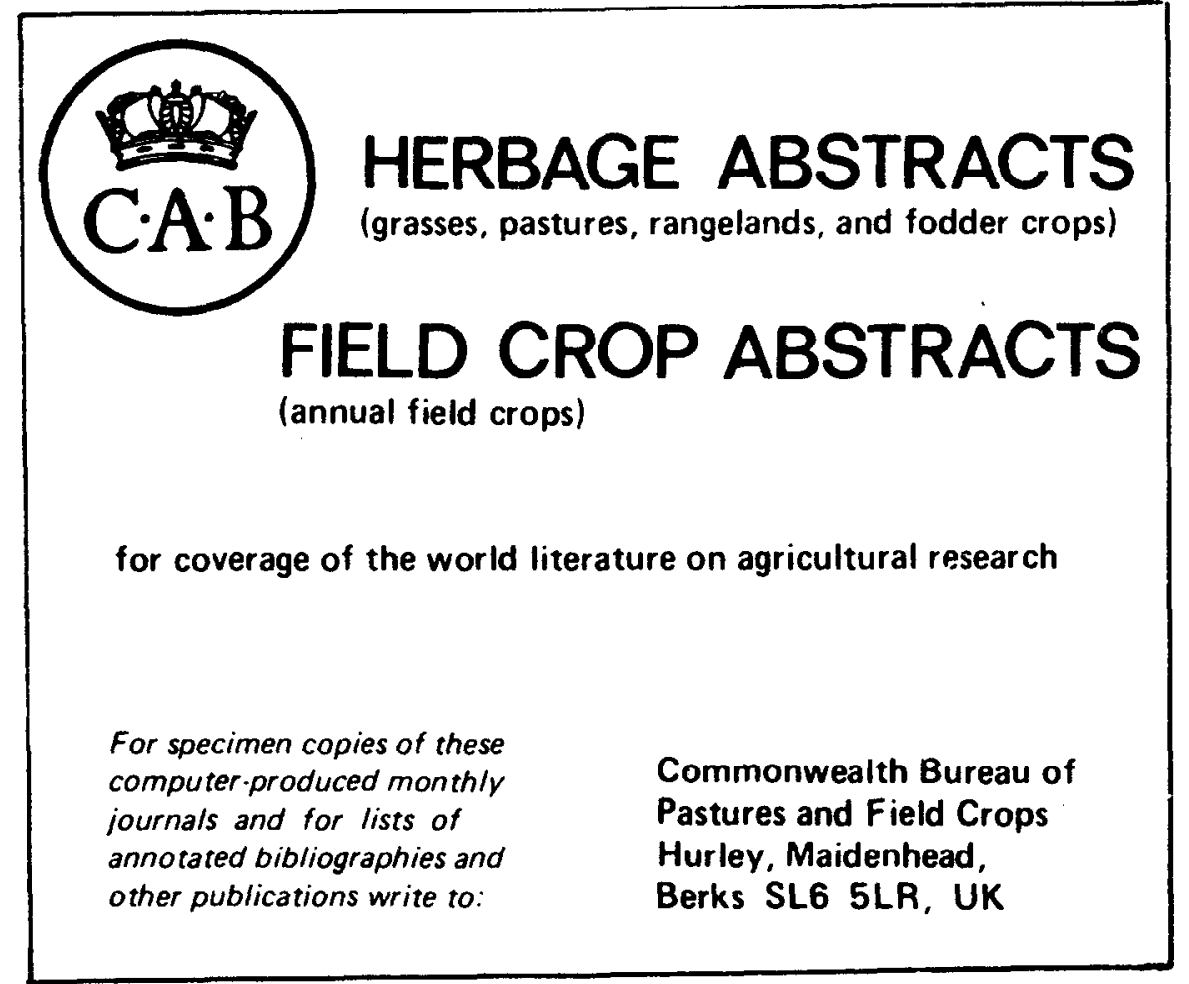

